\title{
ANALISIS KEKUATAN MENGIKAT KONTRAK SEBAGAI DASAR YURIDIS DALAM BISNIS INTERNASIONAL
}

\author{
Cindawati \\ Universitas Palembang \\ Jl. Dharmapala No.1A Bulit Besar Palembang \\ Email: cindawati_s@yahoo.com
}

Diterima: 29 Desember 2016 | Direview: 29 Desember 2016 | Disetujui: 16 Januari 2017

\begin{abstract}
The purpose of this paper to explain and analyze the binding force of the contract as a legal basis in International business. The method applied is normative, which are based on legal principles contained in the law, or set specific standards or norms against a phenomenon by reviewing secondary data or literature. The result is that a contract or agreement as an expression of the will expressed by the offer and acceptance is regarded as a constitutive element of contractual binding force. Supply and demand contains a promise. The new agreement is formed when there is an encounter or an agreement between the promises devoted to one another. Of the nature and scope of a binding legal contract, there are national contract, a contract made by two individuals in an area of the country that no foreign element. While the international contract is a contract with foreign elements. A contract is a legal agreement that can be enforceable, the activities undertaken entrepreneurs. Buy products in one country and sell them in third countries. Firmly binding provision, set the time the contract was agreed upon, signed by both parties. Since starting preparations to transport goods that require funding for preparatory activities up to shipment, payment risks in traveling with the importer. Everything reflects the "rule of the game" has to be clear and detailed. Terms of trade in international trade are to determine the point or place where the seller must fulfill its obligations delivers physical and juridical goods to the buyer. Every business contracts must be preceded with the precision of each of the parties to study the contract clauses, which are generally based on the standard contract or agreement.
\end{abstract}

Key words: binding force, judicial, business contracts

\begin{abstract}
Abstrak
Tujuan penulisan ini untuk menjelaskan dan menganalisis kekuatan mengikat kontrak sebagai dasar yuridis dalam bisnis Internasional. Metode yang diterapkan adalah yuridis normatif, yang berpedoman pada kaidah-kaidah hukum yang terdapat pada perundang-undangan, atau menetapkan standar atau norma tertentu terhadap suatu fenomena dengan mengkaji data sekunder atau kepustakaan. Hasil penelitian: kontrak atau perjanjian sebagai ungkapan kehendak yang dinyatakan dengan penawaran dan penerimaan dianggap sebagai elemen konstitutif dari kekuatan mengikat kontraktual. Penawaran dan permintaan mengandung suatu janji. Perjanjian baru terbentuk jika ada perjumpaan atau kesepakatan antara janji-janji yang ditujukan satu terhadap lainnya. Dari sifat dan ruang lingkup hukum yang mengikat kontrak yaitu ada kontrak nasional adalah kontrak yang dibuat oleh dua individu dalam suatu wilayah negara yang tidak ada unsur asingnya. Sedangkan kontrak internasional adalah kontrak yang ada atau terdapat unsur asing (foreign element). Kontrak: suatu persetujuan legal yang dapat dipaksakan berlakunya, dalam aktivitas yang dilakukan para pengusaha. Membeli produk
\end{abstract}


di suatu negara dan menjualnya di negara ketiga. Ketentuan mengikat tegas, mengatur sejak kontrak disepakati, ditandatangani kedua belah pihak. Sejak mulai persiapan pengiriman barang yang membutuhkan dana untuk kegiatan persiapan sampai dengan pengapalan, resiko dalam perjalanan dengan pembayaran pihak importir. Semuanya mencerminkan "rule of the game" yang jelas dan rinci. Syarat perdagangan dalam perdagangan internasional adalah: untuk menentukan titik atau tempat di mana penjual harus memenuhi kewajibannya melakukan penyerahan barang secara fisik dan yuridis kepada pembeli. Setiap kontrak bisnis harus diawali dengan kecermatan masing-masing pihak untuk mempelajari klausula kontrak, yang pada umumnya berdasarkan kontrak atau perjanjian berstandar.

Kata kunci: kekuatan mengikat, yuridis, kontrak bisnis

\section{Latar Belakang}

Perkembangan di dalam hukum bisnis internasional cukup progresif karena bidang hukum ini diharapkan dapat mengakomodir perkembangan ini melalui aturan-aturan hukumnya. Adanya aturan-aturan ini sangat dibutuhkan bagi pelaku perdagangan untuk adanya kepastian hukum, sekaligus mendapatkan perlindungan hukumnya. Pemikiran dan karya yuridis dari transaksi dan aktivitas bisnis berusaha mewujudkan keseimbangan bagi pihak-pihak yang terasa adil dan wajar. Dalam suatu perjanjian bertimbal balik, seharusnya ada penyerahan yang adil dari kebendaan satu sama lain. Kewajiban salah satu pihak dihadapkan pada kewajiban pihak lain. Sifat timbal balik dalam satu perjanjian merupakan konsep penting untuk memahami kelayakan pertukaran. Dalam suatu perjanjian kenikmatan dan beban tanggung jawab (iusten en lasten) harus dibagi sama rata. Dalam suatu perjanjian jual-beli, pembeli wajib membayar harga jual sebagai sarana untuk mendapatkan barang. Demikian maka kewajiban penjual adalah menyerahkan barang, yang merupakan harga beli. Dasar pembenaran bagi kewajiban salah satu pihak dapat ditemukan dalam kewajiban salah satu pihak, sebaliknya yang dibebankan pada pihak lawan.

Dalam perkembangannya, para pihak terikat dengan adanya kehendak yang bersifat timbal-balik yang saling mengikat untuk mencapai tujuan bersama, sepanjang muatan dan isi perjanjian tidak dilarang oleh undangundang dan persyaratan yang mempunyai kekuatan mengikat, maka kontrak bisnis akan berpegang pada asas keseimbangan yang seolah telah memastikan atau menjanjikan bahwa perjanjian bisnis tersebut akan adil untuk kedua belah pihak. Faktor-faktor yang dapat mengganggu keseimbangan perjanjian ialah: cara terbentuknya perjanjian yang melibatkan pihak-pihak yang berkedudukan tidak setara atau ketidak setaraan prestasiprestasi yang diperjanjikan timbal balik Pada prinsipnya dengan melandaskan diri pada asas-asas hukum kontrak seperti: asas kesepakatan, asas pacta sunt servanda, asas kebebasan berkontrak dan asas keseimbangan, faktor yang menentukan bukanlah kesetaraan prestasi yang diperjanjikan, melainkan kesetaraan para pihak- pihak yakni "keadilan pertukaran" perjanjianlah yang hendak 
dijunjung tinggi. Prestasi yang dijanjikan bertimbal balik mengandaikan kesetaraan, bila terjadi ketidakseimbangan, perhatian akan diberikan terhadap kesetaraan yang terkait pada cara bagaimana perjanjian terbentuk, dan tidak pada hasil akhir prestasi yang ditawarkan secara bertimbal balik. Permasalahan dalam artikel ini adalah bagaimana kekuatan mengikat kontrak sebagai dasar yuridis dalam bisnis Internasional, dengan metode yang diterapkan adalah yuridis normatif, yang berpedoman pada kaidah-kaidah hukum yang terdapat pada perundang-undangan, atau menetapkan standar atau norma tertentu terhadap suatu fenomena dengan mengkaji data sekunder atau kepustakaan.

\section{Pembahasan}

Pengertian Kontrak menurut Blacks Law: ${ }^{1}$

"kontrak sebagai suatu perjanjian antara dua orang atau lebih yang menciptakan kewajiban untuk melakukan atau tidak melakukan suatu tindakan tertentu. ("An agreement betwen two or more persons which creates an obligation to do nor not to do a particular thing")

Dari sifat dan ruang lingkup hukum yang mengikatnya, kontrak dapat berupa kontrak nasional dan internasional. Kontrak nasional ${ }^{2}$ adalah kontrak yang dibuat oleh dua individu (subyek hukum) dalam suatu wilayah negara yang tidak ada unsur asingnya. Sedangkan kontrak internasional adalah suatu kontrak yang didalamnya ada atau terdapat unsur asing (foreign element). ${ }^{3}$ Kontrak: suatu persetujuan legal yang dapat dipaksakan berlakunya, ${ }^{4}$ perjanjian yang biasanya secara tertulis antara dua pihak dalam perdagangan, dan mempunyai kekuatan yang mengikat bagi kedua pihak yang bersangkutan. Kontrak (internasional) dewasa ini merupakan aktivitas sehari-hari. Bentuk kontrak ada yang tertulis dan ada pula yang lisan. Aktivitas ini terutama dilakukan para pengusaha atau pedagang di dunia. Mereka membeli produk di suatu negara dan menjualnya di negara ketiga atau di negaranya.

Dalam transaksi bisnis internasional yang dilakukan oleh penjual (eksportir) dan pembeli (importir) akan timbul hak dan kewajiban bagi masing-masing pihak. Eksportir wajib melakukan penyerahan barang dan berhak untuk menerima pembayaran atas penyerahan barang. Di sisi lain, importir wajib melunasi harga barang dan berhak untuk menuntut penyerahan barang yang dibelinya. Dalam melaksanakan transaksi bisnis internasional itu kebanyakan eksportir dan importir membutuhkan pembiayaan tersebut dari sumber luar perusahaan. Bagi eksportir, pembiayaan disebut pembiayaan ekspor (export financing), terutama dibutuhkan untuk menutup kebutuhan dana modal kerja mereka sebelum atau sesudah pengapalan barang.

1 Blacks Law Dictionary, 5th.ed, (St. Paul Minn: West Publisher, 1949), hlm. 291-292.

2 Sudargo Gautama, Kontrak Dagang Internasional, (Bandung: Alumni, 1976), hlm. 7.

3 Ibid., hlm. 7.

4 M. Dahlan Y. Al-Barry, Kamus Induk Istilah Ilmiah Seri Inteltual, (Surabaya: Target Press, 2003), hlm. 416. 
Sebelum pengapalan barang, eksportir membutuhkan dana untuk membiayai produksi atau pengumpulan barang yang dipesan importir. Adapun yang dimaksud dengan pembiayaan jangka pendek adalah pembiayaan untuk jangka waktu kurang dari satu tahun. Mereka juga membutuhkan dana untuk membiayai persediaan barang yang disimpan dalam gudang sebelum pesanan diterima dari luar negeri atau barang yang diberangkatkan.

Hal di atas menunjukkan bahwa dalam bisnis atau ekspor-impor antar negara (transnasional) lahir berbagai ketentuanketentuan yang mengikat kedua belah pihak (eksportir-importir), atau dengan kata lain bahwa setelah kontrak bisnis disepakati oleh kedua belah pihak, perikatan-perikatan yang lahir dari perjanjian antara para pihak tersebutlah yang menjadi hukum diantara mereka $^{5}$ maka akan timbul undang-undang atau hukum yang hanya berlaku untuk kedua pihak yang mengikatkan diri dalam perjanjian atau kontrak bisnis internasional. Bermuatan ketentuan yang "mengikat" atau adanya akibat hukum bagi kedua belah pihak, maka timbullah "Hukum Bisnis atau Dagang Internasional".

Lahirnya "Hukum" akan merupakan ekspresi atau pencerminan aspirasi dari pihakpihak (pelaku bisnis) untuk perlindungan hak-hak dan kepentingan kedua belah pihak, dengan norma-norma yang bermuatan sanksi bagi pihak yang melakukan wanprestasi. Ketentuan mengikat ini secara tegas telah mengatur sejak kontrak disepakati (ditandatangani) kedua belah pihak. Dalam prinsip pacta sunt servanda berdasarkan prinsip atau aturan dasar ini, para pelaku harus melaksanakan kesepakatan-kesepakatan yang telah disepakatinya dan dituangkan dalam kontrak. Prinsip ini pun sifatnya universal, setiap sistem hukum di dunia menghormati prinsip ini. ${ }^{6}$ Contoh: sejak mulai persiapan pengiriman barang yang membutuhkan dana untuk kegiatan persiapan sampai dengan pengapalan, resiko dalam perjalanan, sehingga kesemuanya terlaksana dengan pembayaran pihak pembeli (importir). Kesemuanya mencerminkan "rule of the game" yang jelas dan rinci. Oleh karena itulah dalam setiap kontrak bisnis harus diawali dengan kecermatan masing-masing pihak untuk mempelajari klausula kontrak, yang pada umumnya berdasarkan kontrak atau perjanjian baku (berstandar). Kecermatan dan kehati-hatian masing-masing pihak adalah faktor antisipatif yang bijaksana. Dalam mewujudkan Hukum bisnis atau perdagangan internasional yang "adil" dibutuhkan suatu prinsip atau asas yang menjamin hak dan kepentingan kedua belah pihak. Asas yang dimaksud adalah "Asas Keseimbangan", yang relatif dapat dimengerti oleh pandangan

5 Satriyo Wahyu Harsoyo, "Tinjauan Yuridis Pengajuan Pembatalan Perjanjian Jual Beli Saham Perusahaan Secara Sepihak", Jurnal Arena Hukum Vol. 8, No. 1, (April 2015): 130, diakses 8 November 2016, doi: http:// dx.doi.org/10.21776/ub.arenahukum.2015.00801.8.

6 Huala Adolf, Hukum Perdagangan Internasional, (Jakarta: RadjaGrafindo Persada, 1995), hlm. 16. 
umum yang mendambakan kedamaian dan keadilan.

Jika para pihak berada dalam situasi normal dan melalui janji-janji yang mereka ajukan membentuk perjanjian, pihak-pihak tersebut dalam perundingan dapat menetapkan sendiri prestasi masing-masing pihak. Tentunya perbuatan hukum demikian jangan berbentuk perbuatan hukum yang melawan undangundang, kesusilaan yang baik, atau ketertiban umum. Para sebenarnya bebas mencari keuntungan sendiri, asal tidak memunculkan situasi yang tidak dapat ditenggang sendiri, asalkan tidak memunculkan situasi yang tidak dapat ditenggang oleh para pihak. Posisi tawar mengakibatkan para pihak berada dalam situasi yang kurang lebih seimbang. Bila keadaannya seimbang, tidak ada seorang pun akan merasa dirugikan. Namun demikian, tentu saja bisa terjadi situasi abnormal dan muncul ketidakseimbangan. Hal ini dapat terjadi bila salah satu pihak yang lebih kuat mengambil keuntungan dari situasi yang lebih menguntungkannya. Maka, tetap situasi ini akan dapat diterima sepanjang tidak menimbulkan keadaan dengan klausul yang tidak wajar, hanya menguntungkan salah satu pihak, yang oleh pihak lawan, karena posisi tawar yang rendah, terpaksa diterima. Situasi demikian merupakan konsekuensi kebebasan yang dapat memuaskan semua pihak, sepanjang pihak lawan tidak mengabaikan hak-hak dan peluang-peluangnya sendiri.
Asas keseimbangan merupakan prinsip yang tidak bernama, kesusilaan yang baik (de goede zeden) dan konstruksi itikad baik (goede trouw contructie), kewajaran dan kepatutan (redeliljkheid en billijk heid), penyalahgunaan keadaan (misbruik van omstandigheden), dan justum pretium sebenarnya dilandaskan pada keadaan yang menuntut adanya keseimbangan dan didalamnya dapat kita kenali semangat atau jiwa keseimbangan. Sebagaimana juga sepatutnya melandasi keputusan-keputusan maupun ketetapan pengadilan. Jika hakim mengetahui adanya penyimpangan yang terlalu jauh tatkala menguji perjanjian terhadap kepentingan umum atau terhadap kepentingan salah satu pihak yang berkehendak mempertahankan perjanjian, konsekuensi dari putusan hakim harus diterima semua pihak. Keberatan melalui intervensi hakim, kepastian hukum akan dikorbankan, tidak perlu dimutlakkan. Pertama-tama, kepastian hukum mutlak tidak mungkin tercapai. Kedua, dalam tahapan selanjutnya dari perjanjian, bukan dalam pembentukannya, melainkan dalam pelaksanaannya justru dengan mengingat kesusilaan yang baik, itikad baik, kepatutan dan kelayakan, serta penyalahgunaan keadaan. Tuntutan kepastian hukum harus ditinggalkan. Hukum tidak dapat memberikan kepastian lebih dari kepastian akan memberi perlakuan sama terhadap kondisi serupa. Yang sama diperlakukan sama, yang berbeda akan mendapat perlakuan berbeda.Bagaimana keseimbangan tercapai adalah persoalan lain. ${ }^{7}$

7 Herlien Budiono, Asas Keseimbangan bagi Hukum Perjanjian Indonesia Hukum Perjanjian berlandaskan Asas-asas Wigati Indonesia, (Bandung: Citra Aditya Bakti, 2006), hlm. 323. 
Di samping tiga tujuan fundamental dari kontrak, memaksakan suatu janji dan melindungi harapan wajar yang muncul darinya, mencegah pengayaan (upaya memperkaya diri) secara tidak adil, untuk mencegah macam-macam kerugian (to prevent certain kinds of harm). Tema penting keseimbangan dicapai dengan melakukan "lompatan" menuju tujuan keempat, suatu tuntutan atau persyaratan yang menurut hemat penulis dinamakan "quantum leaf" dan implementasinya dalam hukum kontrak dinamakan asas keseimbangan. ${ }^{8}$ Di Belanda juga mengatur mengenai asas keseimbangan, mengingat dikenalnya prinsip yang tidak bernama tersebut di atas, tentunya dengan dasar yang mencerminkan cara berpikir khas Belanda. Adanya analisa ini bisa berarti bahwa asas keseimbangan memiliki daya berlaku universal. ${ }^{9}$

Kontrak memiliki tiga tujuan dasar, ${ }^{10}$ sebagai berikut: Tujuan pertama, dari suatu kontrak ialah memaksakan suatu janji dan melindungi harapan wajar yang muncul darinya. Tujuan kedua, dari suatu kontrak ialah mencegah pengayaan (upaya memperkaya diri) yang dilakukan secara tidak adil atau tidak benar. Tujuan ketiga, ialah untuk mencegah macam-macam kerugian (to prevent certain kinds of harm). Di samping ketiga tujuan yang dipaparkan di atas, menurut Herlien
Budiono, ditambahkan tujuan essensial yakni diturunkan dari asas selaras (harmoni), yakni tujuan keempat dari kontrak ialah mencapai keseimbangan antara kepentingan sendiri dan kepentingan terkait dari pihak lawan. Menurut Mariam Darus Badrulzaman, menyebutnya prinsip keseimbangan. ${ }^{11}$ Adanya prestasi timbal balik (resiprositas atau sering juga disebut dengan resiprokal) ini timbul karena adanya kesepakatan timbal balik. Prinsip ini antara lain ditegaskan oleh Hakim Agung Lord Devlin, Common Law Inggris sebagai berikut:

"It is of the essence of every contract that there should be mutuality a contract is an exchange of promises for another... a contract can consist of an exchange of promises on one subject. eg, payment against delivery; the if the seller does not delivery on the due date, the buyer may release himself from his obligation to pay. (Itu adalah inti dari setiap kontrak bahwa harus ada mutualitas kontrak adalah pertukaran janji-janji yang lain..... kontrak dapat terdiri dari pertukaran janjijanji pada satu subjek Misalnya, pembayaran terhadap pengiriman; Jika penjual tidak tidak pengiriman pada tanggal jatuh tempo, pembeli dapat melepaskan dirinya dari kewajibannya untuk membayar). ${ }^{12}$

Janji sebagai titik taut: Perjanjian, ungkapan kehendak yang dinyatakan,

8 Ibid., hlm. 363.

9 Ibid., hlm. 381.

10 Ibid., hlm. 310.

11 Mariam Darus Badrulzaman, Aneka Hukum Bisnis, (Bandung: Alumni, 1994), hlm. 42.

12 Huala Adolf, Dasar-dasar Hukum Kontrak Internasional, (Bandung: Refika Aditama, 2007), hlm. 27. 
penawaran dan penerimaan dianggap sebagai elemen konstitutif dari kekuatan mengikat kontraktual. Penawaran dan permintaan mengandung suatu janji. Namun demikian adanya suatu janji bertimbal balik tidak serta merta membentuk perjanjian. Perjanjian baru terbentuk jika ada perjumpaan atau persesuaian antara janji-janji yang ditujukan satu terhadap lainnya. Kiranya benar, bahwa janji merupakan ungkapan dari kehendak yang dinyatakan, janji yang diberikan mencakup kehendak dan kewenangan untuk mewujudkan janji tersebut. Pentingnya perbuatan dalam bentuk berjanji, yang dalam dirinya sendiri mengimplikasikan kekuatan mengikat, dalam makna yang terkandung dalam dirinya sendiri. Janji adalah faktor potensial, titik taut yang sesungguhnya dikehendaki ataupun sepatutnya dimaksud para pihak dalam rangka menegaskan hubungan hukum tertentu terikat pada kata dan perbuatan, dan kemampuan mewujudkannya.

Dalam Hukum Perjanjian (kontrak), mengenal adanya penghormatan dan pengakuan terhadap prinsip konsensus dan kebebasan para pihak (party autonomy).

Syarat-syarat bisnis atau perdagangan dalam Hak dan Kewajiban para pihak seluruhnya diserahkan kepada para pihak dan hukum menghormati kesepakatan ini yang tertuang dalam perjanjian. ${ }^{13}$ Meskipun kebebasan para pihak sangatlah esensial, namun kebebasan $^{14}$ tersebut ada batasbatasnya.

Ia tunduk pada berbagai pembatasan yang melingkupinya:

a Pembatasan yang utama adalah kebebasan tersebut tidak boleh bertentangan dengan undang-undang, dan dalam taraf tertentu, dengan ketertiban umum, kesusilaan, dan kesopanan.

b Status dari kontrak itu sendiri. Kontrak dalam perdagangan internasional yang ada unsur asingnya. ${ }^{15}$ Artinya kontrak tersebut meskipun di bidang perdagangan internasional paling tidak tunduk dan dibatasi oleh hukum nasional (suatu negara tertentu). ${ }^{16}$

c Mengikatnya para pihak adalah kesepakatan-kesepakatan atau kebiasaan dagang yang sebelumnya dilakukan oleh para pihak yang bersangkutan. Daya mengikat kesepakatan-kesepakatan meskipun tidak tertulis, tetapi mengikat, sebagai berikut:

"In addition to the contractual terms agreed by the parties, the course of past dealings between traders may result in terms becoming part of an agreement between them. These past dealings, or trade usages between the parties, may apply to the contractual relationship despite their not being incorporated into it in written form (Selain persyaratan kontrak yang telah disepakati oleh

13 Pasal 1320 Kitab Undang-undang Hukum Perdata tentang Syahnya Perjanjian.

14 Pasal 1338 Kitab Undang-undang Hukum Perdata tentang Kebebasan Berkontrak.

15 Sudargo Gautama, Hukum Dagang Internasional, (Bandung: Alumni, 1997), hlm. 65.

16 Michelle Sanson, Essential International Trade Law, (Sidney: Cavendish, 2002), p. 7. 
para pihak, bagian selama hubungan antara trader dapat mengakibatkan syarat-syarat yang menjadi bagian dari kesepakatan antara mereka. Terakhir transaksi, atau penggunaan perdagangan antara para pihak, ini mungkin berlaku untuk hubungan kontrak meskipun mereka tidak sedang dimasukkan ke dalamnya dalam bentuk tertulis).

Muatan kontrak bentuknya luas dan berkembang cepat, kontrak tidak sematamata mengenai produk barang. Dewasa ini kontrak telah berkembang dan memuat transaksi di bidang jasa, seperti kontrak konstruksi, kontrak dibidang transportasi dan telekomikasi (misalnya kontrak peluncuran satelit telekomukasi), kontrak di bidang jasa perbankan dan asuransi, pariwisata, jasa entertainment.

Perbedaan dengan bisnis internasional yaitu secara teoritis ada unsur asing yang dapat menjadi indikator suatu kontrak (kontrak nasional yang ada unsur asingnya)

a. Kebangsaan yang berbeda

b. Para pihak memiliki domisili hukum di negara yang berbeda

c. Hukum yang dipilih adalah hukum asing, termasuk atauran-aturan atau prinsipprinsip kontrak internasional terhadap kontrak tersebut.

d. Penyelesaian sengketa kontrak dilangsungkan di luar negeri

e. Pelaksanaan kontrak tersebut di luar negeri f. Kontrak tersebut ditanda tangani di luar negeri

g. Obyek kontrak diluar negeri

h. Bahasa yang digunakan dalam kontrak adalah bahasa asing dan

i. Digunakannya mata uang asing di dalam kontrak tersebut. ${ }^{17}$

Bisnis internasional yang menghendaki kecepatan dan kepastian, salah satunya adalah praktek perdagangan internasional yang sangat menghendaki harmonisasi dan asas keseimbangan, adalah hukum di bidang transportasi, baik laut, darat maupun udara. Hukum yang dimanfaatkan dalam bisnis internasional karena melibatkan banyak negara, maka melibatkan banyak hukum yang tidak seragam, sehingga seringkali banyak permasalahan, yaitu:

a. Kekuatan hukum negosiasi, berbedabeda antara hukum di satu negara dengan negara lain. Ada sistem hukum yang mensyaratkan bahwa negosiasi kontrak belum mengikat sama sekali sebelum kontrak ditandatangani. Sistem hukum di Indonesia (berdasarkan KUHPerdata) menganut sistem ini. Akan tetapi ada sistem di negara tertentu secara tegas menyatakan, bahwa negosiasi tidak mengikat berdasarkan ikatan yang disebut preliminary contract. Apabila terjalin perjanjian akan menimbulkan masalah yang harus diselesaikan di pengadilan. Pada umumnya di negara yang menganut 
Sistem Hukum Common Law. Negosiasi sudah dianggap mengikat. ${ }^{18}$ Pada umumnya pesanan-pesanan (order) pembelian ataupun penjualan ke dan dari luar negeri adalah sebagai hasil dari pembicaraan yang dilakukan sebelumnya antara pembeli dan penjual. Oleh karena pembeli dan penjual dalam jarak yang berjauhan, maka sebagai penghubung (komunikasi) biasanya telah dipergunakan pertukaran surat-menyurat ataupun dengan saling mengirim kawat. Dalam zaman modern ini, di mana faktor waktu sudah sangat diperhitungkan, maka pemakaian kawat telex, telepon dan faksimili sudah menjadi umum dalam melakukan transaksi dengan luar negeri. Di dalam surat-menyurat antara penjual dan pembeli (eksportir dan importir) akan didapati pembicaraan pendahuluan mengenai suatu transaksi yang berisi permintaan penawaran barang, harganya, dan lain-lain syarat. Permintaan penawaran ataupun catatan harga dari calon pembeli kepada calon penjual dalam bahasa asingnya disebut dengan "an inquiry for a quatation" dan pihak penjual (eksportir) mengirimkan suatu penawaran (offer).

b. Akseptasi yang tidak sama dengan tawaran. Akseptasi atau penerimaan tawaran oleh salah satu pihak dalam bisnis internasional tidak persis sama dengan tawaran (offer) yang telah dilakukan oleh pihak lain. Terhadap kejadian seperti ini pengaturan hukum di satu negara dengan negara lain bervariasi. Hukum Perdata Indonesia, menganggap apabila terdapat perbedaan antara offer oleh salah satu pihak dalam akseptasi oleh pihak lain, maka sepakat dianggap tidak terbentuk. Sehingga kontrak belum dianggap terjadi (Pasal 1320 KUHPerdata: Sepakat, kecakapan, suatu hal tertentu dan suatu sebab yang halal). Akan tetapi hukum di USA melihat akseptasi secara gradual, artinya dilihat seberapa jauh penyimpangan dilakukan dalam akseptasi tersebut. ${ }^{19}$ Jika penyimpangannya tidak materiil atau signifikan terhadap kontrak, dan kontrak tetap terjadi dan penyimpangan tersebut, dianggap merupakan bagian dari kontrak. Sebaliknya kalau penyimpangan tersebut bersifat materiil atau signifikan, maka kontrak tetap dianggap telah terjadi, sementara penyimpangan tadi tidak dianggap bagian dari kontrak.

c. Penawaran suatu tawaran. Secara umum di USA menganggap tawaran selalu dapat dibatalkan sebelum adanya kata sepakat. Akan tetapi di negara-negara yang mempunyai ketentuan hukum yang menyatakan penawaran atau offer merupakan perbuatan sepihak, apabila suatu waktu tertentu yang pantas 
(reasonable time) maka offer sudah tidak dapat dicabut lagi, kecuali dibatalkan oleh kedua belah pihak. Penawaran atau offer ini ada bermacam-macam antara lain: Free offer, di mana penjual hanya mencantumkan catatan harga barang yang sifatnya tidak mengikat (without engagement). Di samping itu juga dikenal dengan Firm offer, di mana penjual menentukan baik harga maupun syarat-syarat lainnya untuk suatu jangka waktu tertentu. Pihak pembeli dapat mengambil keputusan yang mengikat dalam jangka waktu itu, dalam arti untuk " menerima penawaran itu beserta syaratsyarat yang disebut"

d. Consideration dalam jual beli, adalah suatu tindakan yang dilakukan atau tidak dilakukan oleh salah satu pihak sebagai imbalan prestasi yang dilakukan oleh pihak lain berdasarkan suatu kontrak. Tanpa adanya kontrak, tidak adanya keharusan baginya untuk melakukan atau tidak melakukan suatu tindakan. Contohnya, pihak pembeli melakukan consideration berupa membayar harga barang tersebut. Di negara menganut Sistem Common Law (Anglo Saxon), consideran merupakan syarat sahnya suatu kontrak dengan beberapa pengecualian dan sudah semakin berkurang daya berlakunya. Sementara di Eropa Kontinental, termasuk Belanda dan Indonesia tidak memberlakukan doktrin consideran.

e. Keharusan kontrak tertulis.

f. Waktu dianggap terjadinya kata sepakat. Beberapa negara yang memberlakukan ketentuan bahwa akseptasi telah terjadi, dan karena itu kata sepakat telah tercapai. Pada saat pihak penerima tawaran tersebut secara wajar mengirim akseptasinya (persetujuannya) kepada pihak yang melakukan offer (tawaran). Apabila dibandingkan dengan BW Belanda Baru (NBW), segi praktis terjadinya kontrak sudah diatur dengan tegas dan mengikuti prinsip-prinsip UNIDROIT ${ }^{20}$ Pasal 217 NBW menyatakan: (1) A contract is formed by formed by an offer and its acceptance, (2) Articles 219-225 apply unless the offer, another juridical act or usage produce a different result. ${ }^{21}$

Dengan maksud dan tujuan: suatu fakta hukum kausalitas dapat menelusuri asal mula atau terjalinan sebab akibat fakta tersebut dengan gejala-gejala lainnya. Di dalam suatu perjanjian para pihak mengungkapkan kehendak mereka dalam bentuk janji. Kenyataan bahwa orang menutup kontrak dilandasi suatu tujuan atau maksud tertentu. Fakta menunjuk pada adanya keterjalinan dengan gejala kemunculan suatu perjanjian, yang dibentuk oleh para pihak, keterikatan

20 Taryana Soenandar, Prinsip-prinsip UNIDROIT Sebagai Sumber Hukum Kontrak dan Penyelesaian Sengketa Bisnis, (Jakarta: Sinar Grafika, 2004), hlm. 109.

21 Ibid. 
atau kekuatan mengikat dan dipenuhinya perikatan. Melalui suatu perjanjian, maksud dan tujuan para pihak dapat dicapai. Tujuan dari perjanjian yang ditutup para pihak dan yang menjadi dasar dari kekuatan mengikatnya secara yuridis. Di samping kekuatan mengikat yuridis, juga ada keterikatan atau kekuatan mengikat dalam perspektif psikologis (rasa terikat) dan sosiologis mengganggap masyarakat terikat. Melalui suatu perjanjian dapat diupayakan perubahan berkenaan dengan pembagian dan pertukaran bendabenda ekonomis maupun jasa yakni sebagai suatu "pergeseran sukarela" (vrijwillige verschuiving), juga ada pergeseran atau pemindahan tidak sukarela, seperti pencurian, perampokan.

Pencapaian tujuan suatu perjanjian dilandaskan pada kehendak yang telah diungkapkan yakni dalam bentuk janjijanji di antara para pihak yang terkait. Di dalam kontrak bisnis merupakan instrumen terpenting untuk mewujudkan perubahanperubahan dalam bentuk pembagian barang dan jasa. Ratio (dasar pemikiran) kontrak merujuk pada tujuan terjadinya pergeseran harta kekayaan secara adil (gerechtvaardigde) dan memunculkan akibat hukum terjadinya pengayaan para pihak secara adil (perjanjian pada prinsipnya mengakibatkan pengayaan secara legal). Kontrak mengejawantahkan ke dalam maksud dan tujuan "menciptakan keadaan yang lebih baik (een beter leven brengen) bagi kedua belah pihak. Agar pertukaran sebagai pengayaan yang adil, dapat dipandang sebagai fair exchange, maka suatu prestasi harus diimbangi dengan kontraprestasi. Pertukaran secara timbal balik merupakan konsep kunci bagi terciptanya keadilan di atas.

Contoh:

Klausula Kontrak Penjualan (Sales Contract)

Dalam menyusun kontrak penjualan (sales contract) relevan untuk diperhatikan ${ }^{22}$ hal-hal sebagai berikut:

1. Uraian barang-barang (description of goods), harus dibuat sejelas-jelasnya oleh kedua belah pihak baik pembeli maupun penjual. Bilamana barang tersebut sudah mempunyai mutu baku internasional (International Standard Quality), maka dalam menentukan mutu disebutkan mutu baku ini, misalnya karet alam, gula, kapas dan sebagainya. Mengenai industri, di samping keterangan tehnik (technical spesification), harus disebutkan nama pabriknya, seperti Singer, Philips, Siemens, dengan melampirkan brochure atau leaflet.

2. Jumlah barang (Quantity), penetapan istilah mengenai kuantum (jumlah barang) harus jelas sehingga tidak mungkin timbul perselisihan tafsiran. Sebagaimana diketahui terdapat bermacam-macam satuan hitung, sehingga dalam hal ini perlu disebutkan dengan lengkap dan sempurna satuan

22 Amir MS., Seluk Beluk dan Tehnik Perdagangan Luar Negeri, (Jakarta: PPM, 2000), hlm. 11. 
hitung yang dimaksudkan. Contoh, 10 ton gula.

3. Harga (price), dalam menentukan harga jual beli, di samping jenis mata uang, harus jelas syarat-syarat penyerahannya harus tegas. Mengenai jenis mata uang harus ditegaskan, misalnya English Pound Sterling, Australian Dollar (A.\$), United States Dollar (US\$), Singapore Dollar (S\$), Hongkong Dollar (H\$), Uni Eropa (Euro).

4. Tempat penyerahan barang (place of deliver), syarat penyerahan barang harus ditentukan secara tepat karena kaitannya untuk menentukan harga dari suatu transaksi, di samping syarat penyerahan barang harus dijelaskan, nama tempat, penyerahan itu akan dilakukan secara phisik. Ini penting untuk mengetahui batas tanggung jawab masing-masing pihak penjual maupun pembeli.

Tujuan pokok memilih "syarat perdagangan" dalam perdagangan internasional adalah untuk menentukan pada titik atau tempat mana penjual harus memenuhi kewajibannya melakukan "penyerahan" barang secara yuridis kepada pembeli "titik" atau "tempat" penyerahan itu, juga merupakan titik batas di mana resiko atas barang (terhadap kehilangan, kerusakan pengangkutan lanjutan dan biaya penimbunan) dari penjual berakhir, dan dari "titik" atau "tempat" itu pula pembeli mulai memikul resiko atas barang itu. Jadi Incoterms mengatur hak dan kewajiban serta biaya dan resiko masing-masing pihak penjual dan pembeli pada setiap syarat perdagangan. ${ }^{23}$

Dalam ketentuan Incoterms 2010, ICC Publication 560 terdapat empat (4) golongan mode transport, yakni:

a. Syarat penyerahan barang yang berlaku untuk semua jenis pengangkutan termasuk multimodal, yang meliputi syarat-syarat:

1) EXW: Ex Works (...... disebutkan tempatnya/ named place);

2) FCA: Free Carrier (.......disebutkan tempat tujuannya/ named place)

3) CIP: Carriage and insurance paid to (.......disebutkan tempat tujuannya/ named place of distination)

4) DAF: Delivered at frontier (....... disebutkan tempatnya/ named place)

5) DDU: Delivered duty unpaid (....... disebutkan tempat tujuannya/ named place of distination )

6) DDP: Delivered duty paid (....... disebutkan tempat tujuannya/ named place of distination)

b. Pengangkutan dengan udara (air transports). Syarat yang digunakan :

FCA: Free Carrier (.......disebutkan tempat tujuannya/ named place)

c. Pengangkutan dengan kereta api. Syarat yang digunakan:

FCA: Free Carrier (.......disebutkan tempat tujuannya/ named place)

d. Pengangkutan laut dan perairan darat (inland water way).

23 Amir M.S., Kontrak Dagang Ekspor, Edisi Revisi, (Jakarta: PPM, 2002), hlm. 17. 
Syarat penyerahan barang yang digunakan:

1) FAS: Free alongside ship (....... disebutkan pelabuhan pengirimannya/ named port of shipment);

2) FOB: Free on board (....... disebutkan pelabuhan pengiriman/ named port of shipment);

3) CFR: Cost and freight (...... disebutkan pelabuhan pengiriman/ named port of distination);

4) CIF: Cost, insurance and freight (....... disebutkan tujuan pelabuhan / named port of distination);

5) DES: Delivered ex ship (....... disebutkan tujuan pelabuhan/ named and distination);

6) DEQ: Delivered ex quay (....... disebutkan tujuan pelabuhan/ named and distination).

Incoterms 2000:

Syarat perdagangan itu seluruhnya dalam kelompok sebagai berikut:

Kelompok E $=$ EXW Ex Works

Kelompok F = FCA Free Carier

FAS Free Alongside Ship

FOB Free On Board

Kelompok $\mathrm{C}=$ CFRCost and Freight CIFCost Insurance Freight CFTCarriage Paid to CIPCarriage and insurance Paid to

Kelompok D = DAFDelivered at Frontier DESDelivered Ex Ship
DEQDelivered Ex Quay

DDUDelivered Duty Unpaid

DDPDelivered Duty Paid

Kelompok $\mathrm{E}=$ Loco Contract

Kelompok F = Shipment Contract

Kelompok $\mathrm{C}=$ Shipment + Transport Contract

Kelompok D $=$ Arrival Contract $^{24}$

Dalam Incoterms 2010 hanya ada 11 istilah yang disederhanakan dari 13 istilah Incoterms 2000, yaitu dengan menambahkan 2 istilah baru dan menggantikan 4 istilah lama. Istilah baru dalam Incoterms 2010 yaitu Delivered at Terminal (DAT); dan Delivered at Place (DAP). Sedangkan 4 istilah lama yang digantikan yaitu: Delivered at Frontier (DAF); Delivered Ex Ship (DES); Delivered Ex Quay (DEQ); Delivered Duty Unpaid (DDU). Pada Incoterms 2010, istilah dibagi dalam 2 kategori berdasar metode pengiriman, yaitu 7 istilah yang berlaku secara umum, dan 4 istilah yang berlaku khusus untuk pengiriman melalui transportasi air.

Syarat perdagangan dalam perdagangan internasional adalah: untuk menentukan titik atau tempat di mana penjual harus memenuhi kewajibannya melakukan penyerahan barang secara fisik dan yuridis kepada pembeli.

Titik atau tempat penyerahan itu juga merupakan titik batas di mana risiko atas barang (terhadap kehilangan, rusak, urusan angkutan lanjutan, dan biaya penimbunan) dari penjual berakhir, dan dari titik atau 
tempat itu pula pembeli mulai memikul risiko atas barang. Syarat perdagangan menurut Incoterms 2000, ICC Publication 560 mulai berlaku sejak 1 Januari 2000, Jakarta.

Incoterms (The International Commercial Terms), dibentuk untuk memberikan definisi baku secara universal mengenai istilahistilah yang digunakan dalam transaksi perdagangan internasional seperti FOB (Free on Board), CIF (Cost, insurance and freight). Praktek perdagangan internasional yang secara standar dan praktis menjadi pedoman dalam form sederhana memotong batasanbatasan hukum kontrak yang tradisional dan rumit. KADIN (Kamar Dagang dan Industri Internasional) atau Incoterms 2010 (International Commercial Terms) sebagai pegangan untuk "sales contract" ke luar negeri dan kontrak-kontrak lanjutannya seperti yang berkaitan dengan perbankan, perusahaan angkutan (EMKL), asuransi, bea cukai, pajak. ${ }^{25}$ Aspek dan elemen penting dalam kontrak standar khususnya Sales Contract. Jika para pengusaha mengadakan perjanjian antara sesama pengusaha umumnya sudah dapat dipahami, bahwa dengan syaratsyarat yang mereka setujui bersama, mereka akan mencapai tujuan ekonomi yang mereka harapkan. Hal ini tidak menimbulkan masalah karena kedua pihak telah memahami makna syarat-syarat yang ditentukan itu.
Syarat-syarat tersebut dirumuskan sedemikian rapi, sehingga menjadi syaratsyarat yang berlaku untuk semua orang yang membuat perjanjian ekonomi dengan pengusaha yang bersangkutan. Dengan kata lain syarat-syarat itu dibakukan, artinya ditetapkan sebagai tolok ukur bagi setiap pihak yang membuat perjanjian ekonomi dengan pengusaha yang bersangkutan. ${ }^{26}$

Perjanjian berstandar disebut juga perjanjian standar, dalam bahasa Inggris disebut Standard Contract, Standard Agreement. Kata "baku" atau "standar", artinya tolok ukur yang dipakai sebagai patokan. Dalam hubungan ini, perjanjian baku artinya perjanjian yang menjadi tolok kukur yang dipakai sebagai patokan atau pedoman bagi setiap konsumen yang mengadakan hubungan hukum dengan pengusaha. Yang dibakukan dalam perjanjian baku, ialah meliputi model, rumusan, dan ukuran. ${ }^{27}$

Hukum Kontrak Internasional dalam Bentuk Kontrak Baku, negara-negara sudah merasakan pentingnya peran bisnis dalam meningkatkan pertumbuhan perekonomiannya. Kesempatan ini disambut oleh pedagang, mereka cukup banyak membentuk berbagai asosiasi dagang sesuai dengan bidang usaha dagangnya. Keberadaan asosiasi dagang ini antara lain bertujuan memfasilitasi dan memperlancar

25 Soedjono Dirdjosisworo, Pengantar Hukum Dagang Internasional, (Bandung: Refika Aditama, 2006), hlm. 37.

26 Ibid., hlm. 51.

27 Ibid., hlm. 55. 
usaha dagang mereka. Salah satu cara atau upaya memfasilitasi ini antara lain adalah memperkenalkan bentuk-bentuk kontrak baku atau standar. Satu hal lain yang perlu diperhatikan dalam kaitannya dengan kontrak baku adalah penuangannya. Kontrak baku atau kontrak standar dapat dicantumkan melalui penguraian dalam dokumen kontrak atau hanya melalui penunjukan saja. Contoh yaitu incorporation of terms by reference, misalnya syarat-syarat perdagangan yaitu FOB (Free on Board) Tanggung jawab hukum dengan syarat perdagangan FOB dengan contoh Kasus Ekspor Impor Pupuk PT Pusri dengan syarat perdagangan FOB (Free on Board)

Contoh Kasus: PT Pusri sebagai eksportir pupuk urea dalam bisnis internasional dengan tujuan ekspor ke negara Filipina, Australia, Cina, Vietnam dan Korea, dengan syarat perdagangan FOB (Free on Board). Tujuan pokok PT Pusri memilih syarat perdagangan ini untuk menentukan titik atau tempat dimana penjual harus memenuhi kewajibannya melakukan penyerahan barang secara fisik dan yuridis kepada pembeli. Titik atau tempat penyerahan itu juga merupakan titik batas dimana risiko atas barang (terhadap kehilangan, kerusakan, urusan angkutan lanjutan dan biaya penimbunan) dari penjual berakhir, dan titik itu pula pembeli mulai menanggung risiko atas barang. Tanggung jawab hukum PT Pusri (sebagai kewajiban) adalah mengurus izin ekspor dan menyerahkan barang sampai di atas kapal pelabuhan muat (laoading port) dari titik atau tempat penyerahan inilah secara fisik dan yuridis sudah beralih dari PT Pusri kepada pembeli. Faktor-faktor yang mempengaruhi PT Pusri memilih syarat perdagangan FOB (Free on Board) ini karena: a) susah mencari kapal atau jumlah kapal dikurangi, b) PT Pusri tidak mau mengambil risiko kerusakan, kehilangan barang, walaupun sebagai penjual (eksportir) PT Pusri menjual harga pupuk Urea lebih murah, pembeli mempunyai kewajiban yang menanggung semua biaya dan risiko kerusakan dan kehilangan mulai dari batas ini. Harga FOB (Free on Board) mencakup harga barang, biaya pengangkutan ke dermaga, serta biaya pengangkutan ke atas kapal.

Dengan adanya perkembangan ini transaksi perdagangan atau bisnis yang modern, kebutuhan akan hukum mengenai kontrak menjadi semakin nyata. Karena kontrak adalah salah satu lembaga yang paling penting di dalam transaksi ekonomi di masyarakat.

Dengan adanya perkembangan ini transaksi perdagangan atau bisnis yang modern, kebutuhan akan hukum mengenai kontrak menjadi semakin nyata. Karena kontrak adalah salah satu persyaratan yang paling penting di dalam transaksi bisnis di masyarakat. 


\section{Simpulan}

Analisis kekuatan mengikat kontrak sebagai dasar yuridis dalam bisnis internasional:

1. Analisis kekuatan mengikat kontrak: yaitu perjanjia dengan ungkapan kehendak yang dinyatakan dengan penawaran dan penerimaan dianggap sebagai elemen konstitutif dari kekuatan mengikat kontraktual. Penawaran dan permintaan mengandung suatu janji. Perjanjian baru terbentuk jika ada perjumpaan atau persesuaian antara janji-janji yang ditujukan satu terhadap lainnya. Pentingnya perbuatan dalam bentuk berjanji, yang dalam dirinya sendiri mengimplikasikan kekuatan mengikat, dalam makna yang terkandung dalam dirinya sendiri. Janji adalah faktor potensial, titik taut yang sesungguhnya dikehendaki ataupun sepatutnya dimaksud para pihak dalam rangka menegaskan hubungan hukum tertentu (terikat pada kata dan perbuatan, dan kemampuan mewujudkannya).

2. Analisis kekuatan mengikat kontrak sebagai dasar yuridis dalam bisnis Internasional: setelah kontrak bisnis disepakati oleh kedua belah pihak, maka akan timbul undang-undang atau hukum yang hanya berlaku untuk kedua pihak yang mengikatkan diri dalam perjanjian atau kontrak bisnis internasional. Bermuatan ketentuan yang "mengikat" adanya akibat hukum bagi kedua belah pihak, maka timbullah "Hukum Bisnis atau Dagang Internasional". Lahirnya "Hukum" akan menjadi ekspresi atau pencerminan aspirasi dari pihak-pihak pelaku bisnis untuk perlindungan hak-hak dan kepentingan kedua belah pihak, dengan norma-norma yang bermuatan sanksi bagi pihak yang melakukan wanprestasi. Kesemuanya mencerminkan "rule of the game" yang jelas dan rinci. Demikian juga mengenai tanggung jawab dan syarat perdagangan untuk menentukan titik atau tempat dimana penjual harus memenuhi kewajibannya melakukan penyerahan barang "secara fisik dan yuridis" kepada pembeli. Syarat perdagangan dalam perdagangan internasional adalah: untuk menentukan titik atau tempat di mana penjual harus memenuhi kewajibannya melakukan penyerahan barang secara fisik dan yuridis kepada pembeli. Untuk itu kontrak bisnis harus diawali dengan kecermatan masing-masing pihak untuk mempelajari klausula kontrak, yang pada umumnya berdasarkan kontrak atau perjanjian baku (berstandar). Kecermatan dan kehati-hatian masing-masing pihak adalah faktor antisipatif yang bijaksana. 


\section{DAFTAR PUSTAKA}

\section{Buku}

Adolf, Huala. Dasar-dasar Hukum Kontrak Internasional. Bandung: Refika Aditama, 2007.

Al-Barry, M. Dahlan.Y. Kamus Induk Istilah Ilmiah Seri Inteltual. Surabaya: Tardet Press, 2003.

Badrulzaman, Mariam Darus. Aneka Hukum Bisnis. Bandung: Alumni, 1994.

Blacks Law Dictionary. $5^{\text {th }}$.ed. St.Paul Minn: West Publisher, 1949.

Budiono, Herlien. Asas Keseimbangan bagi Hukum Perjanjian Indonesia Hukum Perjanjian berlandaskan Asas-asas Wigati Indonesia. Bandung: Citra Aditya Bakti, 2006.

Dirdjosisworo, Soedjono. Pengantar Hukum Dagang Internasional. Bandung: Refika Aditama, 2006.

Gautama, Sudargo. Kontrak Dagang
M.S., Amir. Kontrak Dagang Ekspor. Edisi Revisi. Jakarta: PPM, 2002.

Sanson, Michelle. Essential International Trade Law. Sidney: Cavendish, 2002.

\section{Jurnal}

Harsoyo, Satriyo Wahyu. "Tinjauan Yuridis Pengajuan Pembatalan Perjanjian Jual BeliSahamPerusahaanSecaraSepihak". Jurnal Arena Hukum Vol. 8, No. 1, (April 2015): 130. Diakses 8 November 2016. doi: http://dx.doi.org/10.21776/ ub.arenahukum.2015.00801.8.

\section{Peraturan Perundang-undangan}

Kitab Undang-undang Hukum Perdata

International Commercial Terms 2010.

UNIDROIT (The United Nations Commission on International Trade Law).

ICC Publication 560. Internasional. Bandung: Alumni, 1976. 